\title{
Religion as a Means of Maintaining Legitimacy in the Canadian State
}

\author{
Pat Hart \\ $3^{\text {rd }}$ Year, Bachelor of Laws \\ University of Alberta \\ Edmonton, Alberta
}

"[I]f a system of rules is to be imposed by force on any, there must be a sufficient number who accept it voluntarily. Without their voluntary co-operation, thus creating authority, the coercive power of law and government cannot be established" ${ }^{1}$ - H.L.A. Hart

"For a domination...justification of its legitimacy is much more than a matter of a theoretical or philosophical speculation; it rather constitutes the basis of very real differences in the empirical structure of domination. The reason for this fact lies in the generally observable need of any power, or even of any advantage of life, to justify itself. "2 - Max Weber

\section{Introduction}

In the above quotes, Hart and Weber both point to a requisite element that all nation states share in their quest to maintain a stable order. To appear legitimate, a state must represent itself in a way that is palatable to its citizens. Put differently, a state must convince its populace that the power it wields is rightly wielded. If the majority of its citizens do not accept the legitimacy of the state, then the very stability of the state is undermined; generally, it is only a matter of time before this state is overthrown or reconfigured in a fashion agreeable to the citizenry. ${ }^{3}$ This issue of legitimacy forms the basis of this study. With a focus on Canada, the following will consider a means by which legitimate status is presented and maintained by the state.

\footnotetext{
${ }^{1}$ H.L.A Hart, The Concept of Law, $2^{\text {nd }}$ ed. (Oxford: Clarendon Press, 1994) at 201 [Hart].

${ }^{2}$ Max Weber, On Law in Economy and Society. Trans. Edward Shils (Massachusetts: Harvard University Press, 1969) at 335 [Weber]. It is important to note that Weber devotes a significant amount of discussion to the definition of 'domination'. Broadly speaking, Weber states, "in our terminology domination shall be identical with authoritarian power of command. To be more specific, domination will thus mean the situation in which: The manifested will (command) of the ruler or rulers is meant to influence the conduct of one or more others (the ruled) and actually does influence it in such a way that their conduct to a socially relevant degree occurs as if the ruled had made the content of the command the maxim of their conduct for its very own sake" (Weber at 328).

${ }^{3}$ Hart, supra note 1 at 201.
} 
The route that we will pursue lies in the realm of religion. More specifically, this study will examine how a certain phenomenon, often (but sometimes confusingly) termed "civil religion", functions as means of developing or reinforcing legitimacy. This paper will seek to accomplish three things. First, we will discuss this troublesome concept of "civil religion", as it is a phrase that is neither simply nor universally defined. As such, it is necessary to acknowledge the difficulties associated with the phrase and confine the manner in which the phrase will be used in this study. Secondly, with this in mind, we will look at a few Canadian instances wherein this "civil religion", or something analogous to it, is discernable. This aspect of the discussion will begin by looking at the $19^{\text {th }}$ century case of Pringle v. Napanee ${ }^{4}$, and then shift to the present day with a look at the Charter of Rights and Freedoms ${ }^{5}$ and a recent case, Allen v. County of Renfrew ${ }^{6}$. In the final portion of this paper, it will become evident that the purpose of this study is not limited to simply acknowledging the presence of a religious source for maintaining state legitimacy in Canada; it is also intended to introduce certain concerns that arise from this presence. Ultimately, it will be suggested that future studies on this subject might focus on the notion that Canada is in a transitory condition - religion can serve, and indeed has served, as a means to justify state legitimacy, but it is also a means of justification that is on the decline. As such, the direction of future research needs to consider the possibility of reconfiguring the way in which the legitimacy of the state is justified.

\section{What is "Civil Religion"?}

\section{(a) The Constituent Parts: 'Civil' and 'Religion'}

\footnotetext{
${ }^{4}$ [1878] O.J. No.96. [Pringle].

${ }^{5}$ Part I of the Constitution Act, 1982, being Schedule B to the Canada Act 1982 (U.K.), 1982, c.11 [Charter].

${ }^{6} 69$ O.R. (3d) 742 [2004] O.J. No. 1231.[Allen].
} 
'Civil religion', according to Douglas Farrow, is “harder to define than are its constituent parts". ${ }^{7}$ However, Farrow may overstate how easy it is to define these 'constituent parts'. As such, it is helpful to look at 'civil' and 'religion' individually, and ascertain the way in which these parts will be of benefit to this study.

Without assuming that "civil" is a term devoid of its own set of controversies, we will nonetheless view the term in the manner presented in Webster's dictionary: "civil" is "of, relating to, or involving the general public, their activities, needs, ways, or civic affairs as distinguished from special (as military or religious) affairs". 8 The key is that it holds a quasi-universal character; in other words, 'civil' implies something that can reliably be spoken of in reference to the whole populace of a state. With that said, the immediate problem here is that this definition of civil appears to preclude any connection to religion. Thus, the awkward marriage between the terms 'civil' and 'religion' begins to become apparent - on the surface, civil suggests something that has no connection whatsoever to religion.

We turn now to the next component: "religion". Traditionally, we tend to think that 'religion' involves a belief in a divine or supernatural being(s). Scholars in religious studies generally regard this as an example of a substantive definition of religion. A substantive definition of religion is consistent with the claim that the content of a set of beliefs is determinative on whether this set of beliefs is categorized as a religion. ${ }^{9}$

\footnotetext{
${ }^{7}$ Douglas Farrow, Recognizing Religion in a Secular Society (Montreal \& Kingston: McGill-Queen's University Press, 2004) at 142, note 6 [Farrow].

${ }^{8}$ Merriam-Webster Online Dictionary, s.v. "civil" (fourth entry), online: $<$ http://www.m-w.com>.

${ }^{9}$ The range of discussions pertaining to the difficult nature of the term religion is hardly in short supply. For some early discussion, see: Emile Durkheim, The Elementary Forms of Religious Life. Trans. Carol Cosman (Oxford: Oxford University Press, 2001) [Durkheim]. In recent times, serious discussions of the term 'religion' rarely take place without reference to the work of Jonathan Z. Smith; see Jonathan Z. Smith, Relating Religion: Essays in the Study of Religion (Chicago: University of Chicago Press, 2004). Other
} 
This type of substantive approach, however, is hardly without its shortcomings, and this leads to a consideration that will become relevant to this study. In The Elementary Forms of Religious Life, Emile Durkheim noted certain problems involved in categorizing religion with reference to belief in divine or supernatural beings. Durkheim suggested that this type of method failed to account for belief systems such as Buddhism or Taoism - systems that were generally viewed as religions. ${ }^{10}$ Durkheim thereby claimed that, "we must first know what religion is, what elements it is made of, what caused it, and what function it performs". ${ }^{11}$ This strand of thought has developed into various "functional" definitions of religion, which assert that religion is not so much defined in terms of 'what' is believed, but rather in terms of 'how' beliefs function, or fulfill certain individual or social needs. ${ }^{12}$ Thus, while the religious discussion in this study happens to involve a divinity (God), it is important to keep this functional dimension in mind - for our purposes, we need to focus on the function that God serves. (b) Civil Religion: Rousseau, Bellah, and Beyond

With the individual elements of civil religion briefly addressed, we can return to the whole of the phrase itself. Conceptually, it is helpful to begin with Robert Bellah's Varieties of Civil Religion, as this work often serves as a linchpin for discussions of civil religion. Bellah generally focuses on the concept of civil religion as observable in the American experience, but he is nonetheless helpful in delineating the general boundaries of the term: "While the exact application of the term civil religion can be debated, the

helpful guides include: Peter B. Clarke and Peter Byrne, Religion Defined and Explained, (New York, N.Y.: St. Martin's Press, 1993) [Clarke]; and also Willi Braun and Russell T. McCutcheon, Guide to the Study of Religion, (London; New York: Cassell, 2000).

${ }^{10}$ Durkheim, supra note 8 at 32-35.

${ }^{11}$ Durkheim, supra note 8 at 46.

${ }^{12}$ Durkheim, supra note 8 at pg.29ff. See also Clarke, supra note 8 . 
ubiquity of what can be called "the religio-political problem" can hardly be doubted...Faith and power must always, however uneasily, take a stance toward one another". ${ }^{13}$ This "religio-political problem" is, of course, discernable at many (and perhaps all) historical periods, yet with that said, we will focus on the religio-political problem as it arises during and after the period of the enlightenment, beginning with Jean-Jacques Rousseau's Social Contract. ${ }^{14}$

Rousseau is often credited with coining the phrase "civil religion", which he expounded on in the final chapter of The Social Contract:

The dogmas of civil religion ought to be simple, few in number, precisely fixed, and without explanation or comment. The existence of a powerful, wise, and benevolent Divinity, who foresees and provides the life to come, the happiness of the just, the punishment of the wicked, the sanctity of the social contract and the laws: these are its positive dogmas. Its negative dogmas I would confine to one - intolerance. ${ }^{15}$

By invoking this "powerful, wise, and benevolent Divinity", the state justifies its authoritative position. The state can maintain that its citizens ought to observe the laws of the nation because the authority to make such laws is mandated by the divine. As Farrow puts it, "redoubling of the state's authority by the deployment of theological language ...effectively renders the state itself infallible". ${ }^{16}$

Yet the purpose of civil religion in Rousseau's work is even more precise. Civil religion performs a specific function - it justifies the fact that citizens, through the social contract, give up certain 'natural' freedoms to the state. Farrow summarizes:

The incursion of civil religion into the transcendent sphere is mandated by the citizen's need for special motivation to honour the social contract - a device that, however necessary, unnaturally

\footnotetext{
${ }^{13}$ Robert N. Bellah and Phillip E. Hammond, Varieties of Civil Religion (San Francisco: Harper \& Row, 1980) at vii [Bellah].

${ }^{14}$ Jean-Jacques Rousseau, The Social Contract, C.M Andrews ed. (New York: William H. Wise, 1901) [Rousseau].

${ }^{15}$ Ibid., at 123-124.

${ }^{16}$ Douglas Farrow, Recognizing Religion in a Secular Society (Montreal \& Kingston: McGill-Queen's University Press, 2004) at 150 [Farrow].
} 
constrains human beings - and by the state's need to exercise the ultimate sanctions in defence of that contract. ${ }^{17}$

Thus, we can see how Rousseau's idea of civil religion is particularly helpful for the purposes of this study, since it explicitly addresses the concerns expressed at the onset by Hart and Weber.

Other enlightenment thinkers were hardly ignorant of these same concerns. J.S. Mill did not use the term civil religion, nor did he approach the issue in a strictly religiopolitical sense, but he was nonetheless highly cognizant of the state's need to justify its own authority. Mill suggested that this need is fulfilled by relegating ultimate authority in accord with wherever it is the populace deems such authority to lie. In fact, in a roundabout way, Mill's thought here is simply in line with the statements initially put forward by Hart and Weber. That is, Mill is concerned primarily with maintaining the "political machinery" that comprises a state, and to do this, the majority of citizens must be willing to legitimize the state in some manner - the state cannot function if there is "the repugnance of the people to the particular form of government". ${ }^{18}$ If society believes that ultimate authority lies with a King, then that is how state authority is justified; if society deems that ultimate authority lies with God, then that is how state authority is justified. ${ }^{19}$ With regards to the latter, Mill was attentive to the extraordinary ability of religion in the subject of state legitimization, noting, "religious convictions are something peculiar in their strength". ${ }^{20}$ Thus, while Mill does not state his view in the same sense (or with the same terms) as Rousseau, it is clearly evident that he confronts

\footnotetext{
${ }^{17}$ Ibid., at 149.

18 J.S. Mill, Utilitarianism, Liberty, Representative Government, ed. H.B. Acton (London: J.M. Dent \& Sons Ltd., 1972) at 177 [Mill].

${ }^{19}$ See Chapter I of Representative Government in Mill, ibid.

${ }^{20}$ Ibid at 183-184.
} 
the issue we are concerned with in this study - Mill is fully aware that something must function to maintain the legitimacy of the state.

Moving on, Rousseau's conceptualization of civil religion remained relevant, at least implicitly, during the formation of the American republic. While we will not discuss it in depth here, it can be seen in the correspondence of America's founding fathers Jefferson, Madison, Franklin, etc. In fact, Rousseau's formulation is consistent with Jefferson's view in particular, as Jefferson "[hoped] for a national turn to Unitarianism as the dominant religion, a turn that would have integrated public theology and the formal civil religion much more intimately". ${ }^{21}$ As such, the God discussed by the founding fathers often reflected Unitarian or Deist characteristics; this was a benevolent but otherwise vaguely described divinity, much like the God evident in Rousseau's formulation of civil religion.

This, however, leads to important questions about the adequacy of Rousseau's formulation of civil religion. If taken at face value, does Rousseau's God have any substantive content, or is this God an empty yet powerful vessel that secures the "voluntary co-operation" that Hart deems necessary? Douglas Farrow expresses his concern on this matter:

[If Rousseau's] "sentiments" of civil religion are not susceptible of any precise definition, if indeed it is not clear that they refer to anything actually transcendent, then it is also not clear how they can motivate the citizen. More seriously, it is not clear how they might serve to secure the character of the state to which the citizen is meant to be loyal. The "God" who stands in back of

\footnotetext{
${ }^{21}$ Bella, supra note 12 at 14 . Jefferson himself corresponded with Joseph Priestly, who is often regarded as the founder of Unitarianism. While Jefferson was a practicing Anglican during his lifetime, he was highly supportive of Priestly and expounded views that are regarded as deist in nature. Thus the similarity between Jefferson's ideas and the nature of God in Rousseau's 'civil religion'. Jefferson's views on religion are fascinating, and well deserving of attention unto themselves. For more on this, see Merrill D. Peterson, ed., Thomas Jefferson: Writings, (New York: Library of America, 1994) [Peterson]; see also Daniel L. Dreisbach, "A New Perspective on Jefferson's Views on Church-State Relations: The Virginia Statute for Establishing Religious Freedom in Its Legislative Context," (1991) 35 American Journal of Legal History [Dreisbach].
} 
the state, guaranteeing its right and power to enforce the social contract, may be none other than a projection of the state itself. $^{22}$

Many of Farrow's concerns are worthy of consideration, and we will address some of them in the final part of this study. But for now, it is important that we are not allured too much by Farrow's complaints, since the idea that we are focusing on here is more concerned with the existence and function of a phenomenon, and less concerned with the substantive content or appropriateness of that phenomenon. This phenomenon, as we will call it, has different labels - for Bellah, it is the religio-political problem; for Rousseau it is civil religion; and for Mill, it is not even specifically named. Yet nonetheless, we've noted a common thread even in Mill: religious belief can function, quite powerfully, to help the state legitimize its own authoritative status.

\section{(c) Religion, Civil Religion, and Function}

This focus on function relates back to the discussion of Durkheim earlier, where we addressed the possibility of viewing religion itself in terms of its function. Indeed it is important to remain focused on this matter. Looking again at Rousseau's civil religion, we can explicate this point further. Assuming that Farrow is correct in suggesting that the God of Rousseau's civil religion is, in substance, little more than 'a projection of the state itself', this does not alter the functional purpose of such a God. Rousseau's God appears to refer to something transcendent, and works to induce the citizen to submit to the state - indeed, it works to justify the very legitimacy of the state.

Given this, when we discuss Pringle, Allen, and the Charter below, we are looking at them with an eye towards this functional type of role for religion. For the sake

\footnotetext{
${ }^{22}$ Farrow, supra note 15 at 150.
} 
of convenience, the phenomenon will occasionally be referred to as civil religion, but every effort will be made to ensure that the general phenomenon we are concerned with is not simply reduced to 'civil religion'. Thus the key here is in the endeavor to identify a broader theme: we are looking for instances wherein 'religion' is somehow employed to address the issues first identified by Hart and Weber.

\section{The Phenomenon in Canada: Pringle, Allen, and the Charter}

It is obviously beyond the scope of this study to look at all Canadian jurisprudence that alludes to the issue of where the ultimate source of legal authority lies. Nonetheless, we will do two things here. First, we will look at a $19^{\text {th }}$ century case that demonstrates the presence of some form of the phenomenon discussed above - indeed, it will be associated with religion, yet not entirely consistent with Rousseau's vision of civil religion. Next, we will shift the focus to the present-day, where we will find that the phenomenon continues to exist, yet in a fashion more consistent with Rousseau's formulation.

\section{(a) Pringle v. Napanee (Town)}

Pringle is a case that poignantly demonstrates the intermix between religion (specifically Christianity) and Canadian law in the latter part of the $19^{\text {th }}$ century. In fact, the circumstances of the case, as well as the ruling itself, stand as a fascinating example of how much Christianity was embedded in the very perception of the state.

On three evenings in September of 1874, the plaintiff, Mr. Pringle, scheduled "celebrated Liberal lecturer" ${ }^{23}$ B.F. Underwood to speak at the town hall in Napanee,

\footnotetext{
${ }^{23}$ Pringle supra note 4 at para. 4.
} 
Ontario. The defendants, the town of Napanee, had contracted to rent out the hall for this engagement, but were initially unaware of the subject matter of Underwood's lectures.

After the agreement was reached, however, organizers of the event released

advertisements that made the content of Underwood's proposed topics abundantly clear:

Subject of the first night: 'Evolution v. Creation.' As Darwinism is accepted by almost every scientist of eminence in Europe and America, and is receiving the serious attention of educated men everywhere, this lecture will be exceedingly interesting. Subject, second night: 'What liberalism offers as a substitute for Christianity'. To those who have never examined this question, and who assert that Rationalists have no fixed standard of action, no moral principles or laws to guide and regulate human conduct, this lecture will be a source of enlightenment. Subject, third night: 'Fallacies and Assumptions of Theologians regarding the Bible and Christianity: All who believe in sharing both sides of a question are cordially invited to attend. ${ }^{24}$

The advertisement concluded by citing Milton, as townspeople were encouraged to attend this event where "truth and falsehood [could] grapple". ${ }^{25}$ When members of the town council received word over the nature of Underwood's upcoming lectures, they were horrified, and sought to break the contract with Mr. Pringle, since they felt that the proposed use of the hall was unlawful. In order to achieve a 'proper' contractual breach, the town council passed a resolution that prevented the hall from being used "for a purpose with which the majority of the ratepayers can have no sympathy [and] which cannot fail to be attended with mischievous consequences to many". ${ }^{26}$

Pringle subsequently sued the town of Napanee for breach of contract and indeed, there was little doubt that a contract had been entered into. As such, the Ontario Court of Queen's Bench was faced with the issue of whether or not the Town had any justification for breaching this contract. ${ }^{27}$

\footnotetext{
${ }^{24}$ Ibid.

${ }^{25}$ Ibid.

${ }^{26} \mathrm{Ibid}$., at para. 5

${ }^{27}$ Interestingly, one can find an analogue to the facts of Pringle in Chymyshyn v. Knights of Columbus and Others, 2005 BCHRT 544. Chymyshyn won't be discussed in detail here, but the matter involved a lesbian couple who wished to be married in a Knights of Columbus hall (a private hall, and as such there is some distinction with the Pringle case which involved a public town hall). A British Columbia human rights
} 
The discussion of the court began by considering an issue that is a common trope today, namely, the separation of 'church and state' ${ }^{28}$ In addressing this matter, Chief Justice Harrison affirmed that Canada had no established church, "and since the passing of the Statute chapter 74 of the Consolidated Statutes of Canada, we have not had in the Provinces of Ontario or Quebec even the semblance of any connection between Church and State". ${ }^{29}$ To the contrary, he noted that the Consolidated Statutes of Canada even appeared to promote religious freedom:

That statute declares that the free exercise and enjoyment of religious profession and worship, without discrimination or preference, is by the constitution and laws allowed to all Her Majesty's subjects; and the only qualification of this broad declaration consists in the words of the proviso, "so as the same be not made an excuse for acts of licentiousness or a justification of practices inconsistent with the peace and safety of the Province." ${ }^{30}$

While the limiting proviso may have been influential in the court's final ruling, the court employed this statute primarily to affirm that religious toleration was applicable not only to Christianity, but also to Jews, Muslims, Buddhists, and other faiths. ${ }^{31}$ Despite this, however, the court simultaneously ruled in a manner suggestive of Christianity's privileged status:

An attack upon the life or teaching of Christ is... an attack upon the Christian religion...and...[t]he Christian religion itself was, we think, in 1792 a part of the Common Law of England, and as such, in effect, became a part of the Common Law of this Province. ${ }^{32}$

tribunal confirmed that the Knights, given their affiliation with Catholic beliefs, were within their rights to cancel the agreement, since that the nature of the proposed event was at odds with the tenets of Catholicism. The tribunal added, however, that the Knights ought to have assisted the couple in arranging alternate accommodations for the event, and as such, the Knights were ordered to compensate the women in the amount of $\$ 2000$.

${ }^{28}$ The separation of church and state is, of course, an issue identified more strongly in the American tradition, being commonly (if somewhat mistakenly) associated with Jefferson's famed 1802 letter to the Church in Danbury Letter wherein he spoke of "a wall of separation between church and state" (Peterson, supra note 20). For discussion of the intricacies involved in Jefferson's views on church and state, see Dreisbach, supra note 20.

${ }^{29}$ Pringle, supra note 4 at para. 24.

${ }^{30} \mathrm{Ibid}$., at para. 25.

${ }^{31}$ Ibid., at para. 27.

${ }^{32}$ Ibid., at para. 67. 
The court reached this conclusion after previously asserting that, "Christianity does not need for its support the statute law of any country". ${ }^{33}$ Indeed, it was the other way around: the Christian religion was underlying the laws of Canada, as inherited from England. Given this, the court concluded that the town of Napanee was quite justified in its action - the town had a right to breach the contract, since the proposed use of the hall was one that "the law [held] to be an illegal purpose". 34

While it is plain that Christianity was given preferential treatment in this case, our broader task here is to ask whether there is any hint of the phenomenon discussed or whether there is any indication of religion functioning to legitimize the position of the state. The short answer is "yes", though it comes with a caveat: the phenomenon is manifested in a manner not entirely consistent with the form of civil religion espoused by Rousseau.

This caveat will become clearer when we break down the decision. First, let us look at how the circumstances in Pringle fit in with Hart's concern over voluntary cooperation as a necessary ingredient for state authority. In Pringle, the town's resolution is indicative of the fact that "the majority of the ratepayers" were opposed to Underwood's message. Most of the townspeople in Napanee were Christian, and as such, these townspeople would locate ultimate authority in the divine realm, specifically in God (or Jesus Christ). In fact, Chief Justice Harrison himself subscribed to this notion, a fact discernable in his judgment through remarks such as, "[i]f Christianity be true as we believe it is" 35 or references to "our Lord Jesus Christ and his Apostles"36 (italics added).

${ }^{33} \mathrm{Ibid}$., at para. 32.

${ }^{34}$ Ibid., at para. 96.

${ }^{35}$ Ibid., at para. 33.

${ }^{36} \mathrm{Ibid}$., at para. 67. 
Thus what we see here is something akin to the concept described by Mill - the source of ultimate authority lies exactly where most citizens deem it to lie. And in Pringle, it is clear that most of the populace understood that Christianity was the source of ultimate authority.

In relation to this, we can look to the now familiar sort of function that Christianity would have performed as this source of ultimate authority. By confirming that Christianity was part of the common-law, and in fact pre-dated Canadian law, the court in Pringle reinforced its own authority in a manner that could only have been greeted with applause by most of Napanee's citizens. In Pringle, the nature of this function can, in fact, be elucidated further by once again considering Weber:

Every highly privileged group develops the myth of its natural, especially its blood, superiority. Under conditions of stable distribution of power...that myth is accepted by the negatively privileged layers. Such a situation exists as long as the masses continue in that natural state of theirs in which thought about the order of domination remains but little developed, which means, as long as no urgent needs render the state of affairs "problematical". ${ }^{37}$

In Pringle, the myth relates to the superior status of Christianity. ${ }^{38}$ The ruling of the case, which confirms this myth, ensures that 'the masses continue in that natural state of theirs in which thought about the order of domination remains but little developed'. In fact, if the ruling had been otherwise, it would likely have been a ruling that rendered the state of affairs 'problematical'. This is because such a ruling would have undermined the idea that Christianity retained pre-existing status in the law, and such a finding would surely have caused unrest among Napanee's citizens. That is, it would have begged a few questions: if Christianity is not an underlying root of our law, where is authority

\footnotetext{
${ }^{37}$ Weber, supra note 2 at 336.

${ }^{38}$ Myth is here used in the sense often used by socio-historians, which is to say that it is not intended to be synonymous with the word "false". As put by Richard Wentz, "[m]yths... are not falsehoods, untruths, or misconceptions. They are quite the opposite - they are the imaginative truths by means of which people construct their lives and order their thinking" (Richard E. Wentz, The Culture of Religious Pluralism, Colorado: Westview Press, 1998 at 53).
} 
rooted? And what motivation do we have to abide by the law, if it does not necessarily relate to the morality of our religious beliefs? Thus the function of a ruling like Pringle is clear - it helps to ensure the voluntary co-operation of the citizens with the Canadian state. In fact, in a time period that is still predominantly Christian, Pringle portrays to the citizens that Christianity buttresses (or is at the very least consistent with) the legitimacy of the state.

Indeed, while this is only one case, it is safe to say that Pringle represents a microcosm of Canada during the later part of the $19^{\text {th }}$ century and the early $20^{\text {th }}$ century; the vast number of Canadian citizens adhered to the tenets of Christianity during that time, so locating Christianity as a pre-existing source of law was an effective means of preserving the legitimacy of the Canadian state.

Still, it is relevant to address the fact that Pringle is somewhat inconsistent with Rousseau's civil religion. Rousseau's formulation of civil religion refers to the divine in the vaguest sense possible, and Pringle is a case where this vagueness is not apparent, since the source of law in Pringle was unmistakably affiliated with the precepts of Christianity. Nonetheless, we see that the function of religion in Pringle is consistent with Rousseau's civil religion, as religion in Pringle functions to address the issues outlined by Hart and Weber. This of course is the key point for our purposes, but we can, as a secondary detail, note that Pringle confirms the difficult nature of the phrase 'civil religion'. Thus, if Pringle does not fit squarely in line with any concept of civil religion, it nonetheless helps to confirm the hunch of this study, as we can see in two ways. First, Pringle confirms Mill's idea that if ultimate authority lies wherever society deems it to lie, religion is a particularly powerful force in this regard. Similarly, the concerns of Hart 
and Weber have been addressed - in Pringle, state legitimacy and the voluntary cooperation of the citizens were reinforced through employing a legal analysis that located Christianity as a metaphysical source of law.

In the remaining discussion, we will see the concerns of Hart and Weber tackled in a comparable, but more post-modern manner. This will entail a focus on the Charterera, which will reveal the presence of a phenomenon that is much more in line with Rousseau's idea of civil religion.

\section{(b) The Charter}

The Charter is significant to the discussion at hand because it serves as an example of how legislation (in addition to judicial decisions) can be constructed in a manner that helps to legitimize the authority of a state. The preamble of the Charter includes a reference to God, and this reference suggests that the remainder of the Constitution, and indeed the Canadian state itself, enjoy divine sanction.

Interestingly, there were no references to God in the 1867 Constitution, and references to the divine have been relatively sparse in Canadian legislation. ${ }^{39}$ That said, the absence of God in the 1867 Constitution need not be viewed as significant - it is difficult to think, especially after reading Pringle, that most Canadians didn't see God hovering in the background during the time of Confederation. In any event, the use of God in legislation should not be underestimated as a means of legitimizing both the

\footnotetext{
${ }^{39}$ See, for example, the Lord's Day Act R.S.C., 1952, c. 171. Also of interest is the Canadian Bill of Rights S.C.,1960, c.44, which states the following: "The Parliament of Canada, affirming that the Canadian Nation is founded upon principles that acknowledge the supremacy of God, the dignity and worth of the human person and the position of the family in a society of free men and free institutions". For more discussion of this, see George Egerton, "Trudeau, God, and the Canadian Constitution: Religion, Human rights, and Government Authority in the Making of the 1982 Constitution" in David Lyon and Marguerite Van Die, Rethinking Church, State, and Modernity (Toronto: University of Toronto Press, 2000) [Egerton].
} 
authority of the state and the laws of the state. In the words of Machiavelli, "truly there never was a legislator who, in introducing extraordinary laws into a country, did not have recourse to God, lest his system be rejected outright; for the knowledge of the wise man may not suffice to persuade others". ${ }^{40}$

Nonetheless, the decision to include God in the 1982 Constitution was not without controversy. Prime Minister Pierre Trudeau, for example, objected to the blending of religion and politics, remarking, "I don't think God gives a damn whether he's in the constitution or not". ${ }^{41}$ Yet for all its cleverness, Trudeau's comment misses the point, at least for the purposes of this study. Regardless of whether or not God 'gives a damn' about His presence in the law, it is clearly evident that on its part, the state itself does 'give a damn', as God remains a useful tool in maintaining its legitimacy.

The inclusion of God in the Charter is of course key to understanding the role of God in Charter-era decisions. His presence lies in the preamble of the Charter, which states, "Whereas Canada is founded upon principles that recognize the supremacy of God and the rule of law". ${ }^{42}$ The obvious question therefore is: of what significance is the preamble of a document? While the preamble of a statute does not have the same effect as the actual provisions of the statute, it is still significant. For his part, Peter Hogg states, "[a] preamble to a statute (or constitution) has no direct force, but may be used as an aid in the interpretation of the other provisions". ${ }^{43}$ We will address the legal effect of the preamble further in the discussion of Allen below.

\footnotetext{
40 Niccolo Machiavelli, Discourses on Livy. Trans. Harvey C. Mansfield and Nathan Tarcov (Chicago: University of Chicago Press, 1996) at 35.

${ }^{41}$ Liberal Caucus, April 1981.

${ }^{42}$ Charter, supra note 5.

${ }^{43}$ Peter Hogg, Canada Act 1982 Annotated, (Toronto: Carswell, 1982) at 5 [Hogg].
} 
There is, however, a more immediate problem with the preamble, and it lies in the fact that it is inconsistent with s.2 (a) of the Charter, which stipulates that everyone has the fundamental freedoms of "freedom of conscience and religion". ${ }^{44}$ The upshot of this, as Hogg states, is that, "the reference to "God" does not seem helpful in construing s.2(a) of the Charter... because the reference to conscience in s.2(a) must surely protect systems of belief which do not accept the existence of God". ${ }^{45}$ In other words, while a belief in God appears to inform the very content of the Charter, s.2(a) suggests that citizens are under no obligation to even believe in God.

Thus, we are presented with the double-edged status of God in the Constitution. On the one hand, the preamble offers a potential means by which state authority can be sanctified. On the other, the late $20^{\text {th }}$ and early $21^{\text {st }}$ century is a period wherein Canada, a self-described liberal state, is highly cognizant of the danger in situating absolute authority. More specifically, the inclusion of God in the Preamble undermines the pluralistic goal of s.2(a). Roberto Unger highlights the task faced by the modern liberal state:

The liberal state needs a law sufficiently secular to reflect changing social values and power relations. It presupposes that no one group in the society has a privileged access to religious and moral truth. ${ }^{46}$

With this said, one can see how the Rousseauian model of civil religion makes sense to a certain extent; it is, at the very least, a highly inoffensive means of employing religion to legitimize the state. Notwithstanding the s.2(a) problem, the vague and all encompassing God of the Charter is valuable in exhibiting the legitimacy of the state to a large audience - the Charter God is one that can be recognized by a wide-array of religious groups:

${ }^{44}$ Charter, supra note 5, at s.2(a).

${ }^{45}$ Hogg, supra note 42 at 5.

${ }^{46}$ Roberto Unger, Law in Modern Society: Toward a Criticism of Social Theory, (London: Collier Macmillan Publishers, 1976) at 84 [Unger]. 
Christians, Muslims, Jews, and Deists, for example. Nonetheless, it is clear that s.2(a) does cause unmistakable tension. The case of Allen serves as an example of how this tension plays out, and how the Charter preamble can be activated by the judiciary on an as needed basis.

\section{(c) Allen v. Corporation of the County of Renfrew}

Since 1861, the County of Renfrew's council meetings commenced by reciting the Lord's Prayer. After November 29, 2000, this changed, as Frietag v. Penetanguishene (Town) ${ }^{47}$ established that the use of the Lord's Prayer in council meetings was contrary to s.2(a) of the Charter. Cognizant of this decision, the County of Renfrew formulated a new 'non-sectarian' prayer based on one used in the House of

\section{Commons:}

Almighty God, we give thanks for the great blessings which have been bestowed on Canada and its citizens, including the gifts of freedom, opportunity, and peace that we enjoy. Guide us in our deliberations as [County Councilors], and strengthen us in our awareness of our duties and responsibilities. Grant us wisdom, knowledge, and understanding to preserve the blessings of this country for the benefit of all and to make good laws and wise decisions. Amen. ${ }^{48}$

Despite this reformulation, the applicant, Robert Allen, argued that the prayer still violated his Charter right to freedom of conscience and religion. This objection was not taken lightly among members of the community. The circumstances of the case indicate that most citizens in the County of Renfrew held deeply rooted religious beliefs, not unlike the citizens of Napanee in the Pringle case. In fact, Allen had received mail from other residents "which he considered offensive", and it had apparently escalated to a

\footnotetext{
${ }^{47}$ (1999) 47 O.R. (3d) 301.

${ }^{48}$ Allen, supra note 6 at para. 3.
} 
point where Allen "was planning to relocate to Ottawa where he hoped he would feel more comfortable in terms of his beliefs". 49

Nonetheless, the court was, of course, obliged to address Allen's complaint. In doing so, it relied heavily on the expert testimony of Professor Antonio Gualtieri, who testified that the revised prayer was not non-sectarian in nature, as it was "not sufficiently generic to include certain belief systems such as [Allen's], which do not accept God, but are nonetheless regarded as religions". 50 This type of objection reaffirms the value of Durkheim's functional view of religion and - more importantly here - speaks to Hogg's identification of the problem between the reference to God in the Charter preamble and the content of s. 2(a) itself.

Having acknowledged Gualtieri’s remarks, however, the court subsequently concluded that the only way around the problem was to have a prayer that did not refer to God. This, the court observed, was no solution at all, since "[a] truly non-sectarian prayer in the terms envisioned by Dr. Gualtieri (without reference to a divine being) would not be a prayer as normally understood". 51

Nonetheless, the court still had to deal with the effect of the preamble, in light of s. 2(a). On the one hand, it acknowledged that "[w]hatever meaning may be ascribed to the reference in the preamble to the "supremacy of God", it cannot detract from the freedom of conscience and religion guaranteed by s.2(a)". ${ }^{52}$ On the other hand, Justice Hackland cited the Supreme Court ruling in Remuneration of Judges of the Provincial

${ }^{49}$ Allen, supra note 6 at para. 10.

${ }^{50}$ Allen, supra note 6 at para. 14.

51 Allen, supra note 6 at para. 15.

${ }^{52}$ Allen, supra note 6 at para. 20. 
Court of Prince Edward Island $(R e)^{53}$, where the court noted, "the preamble is not only a key to construing the express provisions of the Constitution...but also...is the means by which the underlying logic of the Act can be given the force of law". ${ }^{54}$ Given this authoritative statement by the Supreme Court, Justice Hackland had no problem in reaching the following conclusion:

I do not accept the proposition that the mere mention of God in a prayer in a governmental meeting, accompanied by the implication that God is the source of the values referred to in the prayer, can be seen as a coercive effort to compel religious observance...In a pluralistic society, religious, moral or cultural values put forward in a public governmental context cannot always be expected to meet with universal acceptance...In my view, it would be incongruous and contrary to the intent of the Charter to hold that the practice of offering a prayer to God per se is a violation of the religious freedom of non-believers. This conclusion derives considerable support from the fact that the preamble to the Charter itself specifically refers to the supremacy of God. ${ }^{55}$

The court thus employed the preamble to support the proposition that certain actions were just too trivial to warrant s.2(a) protection. As Justice Hackland suggested, "While there is no question that the principles protected by s.2(a) of the Charter include the right to be free from direct or indirect coercion to act in a way contrary to one's beliefs and the freedom not to conform to the religious practices of the majority, including in the context of public County Council meetings, this does not mean that every minor affront to one's beliefs is a violation of one's freedom of religion as protected by the Charter". ${ }^{56}$

In certain respects, Allen is very comparable to Pringle. In both cases, we have circumstances where the majority of the citizens are in support of the law, or practice, that would reflect the presence of some source of authority that relates to religious belief. In Pringle, it is evident through the ruling that Christianity was inherited as part of the common law; in Allen, it is evident in the fact that most citizens were supportive, or at worst indifferent, to the idea of praying for God to offer guidance in Council meetings.

${ }^{53}$ [1997] 3 S.C.R. 3.

${ }^{54}$ Cited from Allen, supra note 6 at para. 20.

${ }_{56}^{55}$ Allen, supra note 6 at para. 19.

${ }^{56}$ Allen, supra note 6 at para. 26. 
Both of these were cases wherein the metaphysical beliefs of the majority were cleverly, if not consciously, promoted by the courts in a manner that reinforced the legitimacy of the state.

In fact, in Allen, we can actually view the presence of Rousseau's civil religion in two ways. First, the presence of the prayer itself is indicative of the phenomenon. The content of the prayer identifies a non-denominational God as the ultimate authority, and also implies that God is somehow causally connected to the council's actions. Indeed, the practice is one that the House of Commons partake in as well. Second, as noted earlier, the preamble itself serves as an indicator of some pre-existing divine source that informs the Constitution and the legitimacy of the state.

\section{Conclusion: Criticisms of the Phenomenon, and the Future Course}

Thus we have looked at a few cases, in addition to the Charter itself, for evidence that religion can be implicated in the quest to determine the grounds upon which state legitimization is established or maintained. Nonetheless, there are clearly problems with this that ought to be given due attention. One, as encountered in the Charter, relates to the contradiction between the preamble and s.2(a). Another angle of criticism was briefly acknowledged earlier in a quote from Farrow, who critiqued the bland Rousseauian conceptualization of civil religion on a few fronts. First, Farrow suggested that if it wasn't clear that civil religion actually referred to anything, how could it motivate the citizen? Second, he asked how this 'secure[s] the character of the state to which the citizen is meant to be loyal'; if God is nothing more than a projection of the state, then how does that reflect upon the state? In other words: how does the state retain its 
legitimate status if its citizens are wise to its tricks and wary of the authoritative status of religion? How does the state retain its legitimate status when 'the jig is up'?

Thus we see how Farrow is troubled by the vague substance of Rousseau's civil religion and skeptical of the very prospect that citizens might even fall prey to this type of scheme. We pushed these sorts of questions aside earlier, because we were focusing on the existence and function of the phenomenon. Given the data to this point, it is evident that we have succeeded in accounting for a few examples wherein religion was invoked in a manner that helped legitimize the state. Again, this is not to suggest that it is a phenomenon that is consciously pursued, but it is one that is nonetheless discernable. As such, whether Farrow likes it or not, it is plain that Rousseau's civil religion is alive, as a subset in a broader category that relates to the use of religion in state legitimization.

Yet Farrow's concerns deserve further attention; we have indicated that the above phenomenon does occur, but can we investigate the question of why or how it occurs? In exploring these issues we will consider a few things. First, let us begin by delineating a soft boundary - when addressing Farrow's concerns, we are speaking primarily in reference to Rousseau's civil religion, which we have found present in the Charter. So with this given, let us restate Farrow's first question: how can civil religion, as apparent in the Charter, motivate the citizen if it does not really refer to anything?

Farrow's rhetorical question makes at least one strong assumption. He assumes that civil religion does not refer to any sincere conviction, and in relation to this, assumes that citizens realize that this is the case. Such assumptions can be entertained, but are not categorically accurate. What is key here is the manner in which the citizen engages civil religion. In other words, when a citizen with theistic beliefs considers the presence of 
God in the Charter, she undoubtedly tends to explicate that God in accord with her own previously entrenched beliefs. The Charter, or a Parliamentary prayer, locates God in the authoritative scheme, and then individual citizens fill in the requisite substance of that Deity. Thus civil religion's God is not really an empty vessel - at least not in the eyes of citizens who hold theistic beliefs. Admittedly, the state can be criticized for inappropriately setting certain wheels in motion by presenting this widely acceptable God to the citizens, but this is precisely the point in Rousseau's civil religion. The state posits or affirms an ambiguous non-temporal source that sanctions state authority and subsequently lets citizens fill in the blanks in a manner that is acceptable to them. The upshot of this is that once the citizen has filled in these blanks, he cannot help but yield to the now-legitimized authority of the state. Indeed, the arrangement might even be viewed as reciprocal - the citizen yields to the state, and the state, through positioning God in its authoritative scheme, reinforces the religious beliefs of the citizen.

Still, this explanation does not account for all Canadian citizens, and this leads to the final part of this study. We need to be cognizant of the fact that there are a growing number of citizens who are not willing to accept the state's initial move toward the idea that its authority is divinely sanctioned. ${ }^{57}$ Indeed, Allen is suggestive of this reality, and the fact that the state and judiciary rarely invoke the preamble indicates their own awareness of how many citizens share Mr. Allen's convictions. Thus the question arises: if God is no longer effective as a means of convincing citizens that the state is legitimate, then what is? This is the question that future studies, and ultimately the state itself, will have to address.

\footnotetext{
${ }^{57}$ This claim is slightly impeded when one considers that some immigrants, such as Muslims, enter Canada with already-established monotheistic beliefs. The magnitude of this consideration is difficult to estimate without statistical assessments, but it is nonetheless noteworthy.
} 
We can delve into this issue to a small degree by returning to the issue of the Charter preamble, and the context in which it came to be, historically. Canada's inclusion of the reference to God was clearly odd to some, even in 1982. As George Egerton notes, "[i]t is doubtful if the Canadian political elites of 1982 were as firm as the patriarchs of 1867 in their devotion to the supremacy of God. Indeed, the language of the preamble seemed somewhat anachronistic in an increasingly secular age which had witnessed the retrenchment of religion in public life". ${ }^{58}$ Egerton's assertion overlooks what has become obvious in this study, namely that God is a tremendous force in justifying the legitimacy of a state. Nonetheless, he is warranted in wondering whether God was included with noble intentions. The problem, however, is that the possibility of justifying state authority without reference to God is one that is relatively unproven in North America. Thus we are left with the status quo, but one that is in a precarious position. Unger explains the nature of the problem:

What happens when the positive rules of the state lose all touch with a higher law and come to be seen as nothing more than the outcomes of a power struggle? Can the ideals of autonomy and generality in law survive the demise of the religious beliefs that presided over their birth?...And is the legal system, perhaps, a transitory characteristic of societies in which the divine and the political order are separated yet not wholly estranged from one another. ${ }^{59}$

While civil religion is still present in Canada to some degree, there can be little doubt that in the $21^{\text {st }}$ century, its effectiveness is diminishing. Put more bluntly, there are likely more Robert Allens today then there were at the time of a case like Pringle. More citizens are attuned to, and indeed more suspicious of, the peculiar ability of religion as a way to legitimize authority.

So where does that leave us? The answer is uncertain, as our nation is in a state of flux in this regard. Indeed, it is an issue that goes well beyond Canada. As Egerton

\footnotetext{
${ }^{58}$ Egerton, supra note 38 at 91.

${ }^{59}$ Unger, supra note 45 at 83.
} 
notes, "[t]he capacity of modern democratic governments to perform successfully without religious legitimations has a very brief and untested history" ${ }^{60}$ In fact, it is possible to argue that our Canadian state really hasn't performed without religious legitimations. Allen, as well as the Charter preamble, confirms this. Furthermore, the invocation of God in the speeches of Prime Minister Harper demonstrate that while civil religion might be on the decline, it is clearly not dead. ${ }^{61}$

Yet if civil religion is nonetheless a slowly dying phenomenon, it opens up a gap wherein the issue of state legitimacy must be addressed in another way. To some, this might not seem like a significant task. To put the matter more plainly, many would argue that a state could function without positing God as an ultimate authoritative figure. Indeed, Mill would clearly entertain this possibility, though he would also insist that some form of ultimate justification is still required. That is, if the citizens of a nation are unconvinced by the idea that justification can be posited in the divine realm, this does not change the fact that justification must still be posited somewhere, in order for the state to retain legitimacy.

How, then, is the state to proceed on this matter? On the one hand, if the state suddenly and explicitly reconfigured its claim to legitimacy in a manner rooted in some type of humanism, much of the population would strongly object. Indeed, the level of objection might be sufficient to undermine the voluntary cooperation required to maintain legitimate status. On the other hand, a stronger push towards civil religion would also be frowned upon by another section of Canadian citizens. The judiciary, and to a lesser

\footnotetext{
${ }^{60}$ Egerton, supra note 38 at page 109-110.

${ }^{61}$ Prime Minister Harper has been known to close his speeches with the words, "God bless Canada". Note, for example, his victory speech following the January 23, 2006 election; Stephen Harper, "Canadians choose change and accountability", online: The Conservative Party website $<$ http://www.conservative.ca/EN/1004/40299>.
} 
extent Parliament, are cognizant of this reality. Thus we live in the present situation wherein the source of state legitimacy is uncertain - at times it appears to lie in the divine realm, as per civil religion, yet at others, state authority is wielded without reference to any source that lies beyond the state itself.

If writers such as Hart and Weber are correct, then this irregular status does little to ensure longevity of the state. The question remains, however, as to whether it will suffice for the time being - until a time when the state, as per Mill, explicitly (re)locates ultimate authority in a manner that is acceptable to the majority of its citizens.

The answer to how long the status quo can remain, and how the state can reform the manner in which it legitimizes itself, cannot be addressed here. Nonetheless, the preceding has provided information that should aid in determining the direction of such a study. First, it would be necessary to confirm the hunch of this paper, a hunch that suggests that case law and legislation do indicate the presence of civil religion in Canada today. We have noted this in the decision of Allen and the preamble of the Charter, but a broader number of cases would need to be investigated, with specific attention to the Charter-era, an era wherein God enjoys constitutional recognition. This investigation would, in itself, also aid in evaluating our assertion that civil religion is a phenomenon that is slowly but surely waning. By accounting for cases that are favorable to the notion of civil religion, one can simultaneously confirm whether such cases are in a steady decline over recent generations. Once that diagnostic aspect is confirmed, it would become necessary to look to other places and time periods in which the ultimate source of state authority shifted in a drastic manner. Indeed the closest analogue might be found in the enlightenment period and the decline of theocratic nations. Finally, such a study 
would utilize this information to determine the stability of nations during these shifts, and the level at which such states effectively functioned. Ultimately, such a study would aid in providing both prognosis and treatment for a Canadian state that appears to slide closer toward a period wherein its own legitimacy lies in a state of ambiguity.

\section{BIBLIOGRAPHY}

\section{LEGISLATION}

Canadian Bill of Rights S.C.,1960, c.44.

Canadian Charter of Rights and Freedoms. Part I of the Constitution Act, 1982, being Schedule B to the Canada Act 1982 (U.K.), 1982, c.11.

Lord's Day Act R.S.C., 1952, c. 171.

\section{JURISPRUDENCE}

Allen v. County of Renfrew 69 O.R. (3d) 742 [2004] O.J. No. 1231.

Chymyshyn v. Knights of Columbus and Others, 2005 BCHRT 544.

Frietag v. Penetanguishene (Town) (1999) 47 O.R. (3d) 301.

Pringle v. Napanee [1878] O.J. No.96.

Remuneration of Judges of the Provincial Court of Prince Edward Island (Re) [1997] 3 S.C.R. 3.

\section{MONOGRAPHS}

Bellah, Robert N. \& Hammond, Phillip E. Varieties of Civil Religion (San Francisco: Harper \& Row, 1980).

Braun, Willi \& McCutcheon, Russell. Guide to the Study of Religion (London; New York: Cassell, 2000).

Clarke, Peter B. \& Byrne, Peter. Religion Defined and Explained (New York, N.Y.: St. Martin's Press, 1993).

Durkheim, Emile. The Elementary Forms of Religious Life, Trans. Carol Cosman 
(Oxford: Oxford University Press, 2001).

Farrow, Douglas. Recognizing Religion in a Secular Society (Montreal \& Kingston: McGill-Queen's University Press, 2004).

Hart, H.L.A. The Concept of Law, $2^{\text {nd }}$ ed. (Oxford: Clarendon Press, 1994).

Hogg, P.W. Canada Act 1982 Annotated (Toronto: The Carswell Company Limited, 1982).

Machiavelli, Niccolo. Discourses on Livy, Trans. Harvey C. Mansfield and Nathan Tarcov (Chicago: University of Chicago Press, 1996).

Mill, J.S. Utilitarianism, Liberty, Representative Government, ed. H.B. Acton (London: J.M. Dent \& Sons Ltd., 1972).

Peterson, Merrill D. ed., Thomas Jefferson: Writings (New York: Library of America, 1994).

Rousseau, Jean Jacques. The Social Contract, C.M Andrews ed. (New York: William H. Wise, 1901).

Smith, Jonathan Z., Relating Religion: Essays in the Study of Religion (Chicago: University of Chicago Press, 2004).

Unger, Roberto. Law in Modern Society: Toward a Criticism of Social Theory (London: Collier Macmillan Publishers, 1976).

Weber, Max. On Law in Economy and Society. Trans. Edward Shils (Massachusetts: Harvard University Press, 1969).

Wentz, Richard E. The Culture of Religious Pluralism (Colorado: Westview Press, 1998).

\section{ARTICLES}

Dreisbach, Daniel L. "A New Perspective on Jefferson's Views on Church-State Relations: The Virginia Statute for Establishing Religious Freedom in Its Legislative Context," (1991) 35 American Journal of Legal History.

Egerton, George. "Trudeau, God, and the Canadian Constitution: Religion, Human rights, and Government Authority in the Making of the 1982 Constitution" in David Lyon and Marguerite Van Die, Rethinking Church, State, and Modernity (Toronto: University of Toronto Press, 2000). 